\title{
Temporal variations of CAT, GSH, and LPO in gills and livers of zebrafish, Danio rerio, exposed to dimethoate
}

\author{
Shabnam Ansari, Badre Alam Ansari
}

Received - 08 March 2013/Accepted - 02 February 2014. Published online: 30 June 2014; $\odot$ Inland Fisheries Institute in Olsztyn, Poland Citation: Ansari S., Ansari B.A. 2014 - Temporal variations of CAT, GSH, and LPO in gills and livers of zebrafish, Danio rerio, exposed to dimethoate - Arch. Pol. Fish. 22: 101-109.

\begin{abstract}
Pesticides are designed to kill a very wide range of undesirable organisms, but they simultaneously adversely affect non-target organisms in ecosystems. Dimethoate is an organophosphorous insecticide used widely in agriculture that has an anticholinesterase mode of action. The goal of the study was to assess the effects of dimethoate on catalase, reduced glutathione, and lipid peroxidation in the gills and livers of zebrafish, Danio rerio (Hamilton), exposed to different concentrations of the pesticide for different periods of time. Insecticidal stress caused a reduction in catalase activity and reduced glutathione levels in zebrafish gills and livers. There was also increased lipid peroxidation in both organs. Alterations in all parameters were concentration and time dependent. The probable causes are discussed.
\end{abstract}

Keywords: Danio rerio, dimethoate, biomarkers, oxidative stress, anti-oxidants

\section{Introduction}

Contaminating water bodies with widely-used pesticides is a potential problem for aquaculture. The benefits of pesticides include being able to control vector-borne diseases, and increased agricultural

\footnotetext{
B.A. Ansari [ झ], S. Ansari

Zebrafish Laboratory, Department of Zoology

D.D.U. Gorakhpur University

Gorakhpur - 273009 (U.P.) India

e-mail: ba.ansari@rediffmail.com
}

productivity by controlling pests; however, pesticides finally find their way into natural water bodies and affect aquatic environments. Aquatic organisms, including fish, accumulate pollutants directly from contaminated water and indirectly via the food chain. Pesticides can damage vital organs (Ansari and Ansari 2012), reduce reproductive ability (Ansari and Ansari 2011), and cause various biochemical alterations (Sharma et al. 2012) in fish. Dimethoate, an organophosphorus pesticide that was first described by Hoegberg and Cassady (1951), is used against a broad range of insects in agriculture and also to control the common housefly. Its mode of action is acetylcholinesterase (AChE) inhibition resulting in nerve exhaustion, nervous system failure, and, ultimately, in death. It is moderately toxic to birds and mammals (Riebeiro et al. 2003).

Pesticide metabolism generates reactive oxygen species (ROS) (Gram 1997), which are highly reactive oxidizing agents belonging to the free radical class. A free radical is any compound, not necessarily derived from oxygen, that contains one or more unpaired electrons. Oxidative stress is a condition associated with an increased rate of cellular damage induced by oxygen and oxygen-derived oxidants commonly known as ROS (Sikka et al. 1995). Severe oxidative stress can cause cellular lesions and, finally, cell death. Numerous studies indicate that dimethoate intoxication can cause oxidative stress by 
generating free radicals and inducing hepatic lipid peroxidation in mice (Gultekin et al. 2000). By estimating the enzyme activities in an organism, we can easily identify disturbances in its metabolism. About $5 \%$ or more of inhaled oxygen is converted to ROS by the univalent reduction of $\mathrm{O}_{2}$ (Maxwell 1995). Antioxidants can act by scavenging ROS, inhibiting their formation, blocking the activation of phagocytes, binding the transition of metal ions, and preventing the formation of $\mathrm{OH}$, or decomposing lipid hydroperoxides (Niwa et al. 2001). Detoxification batteries have evolved in aerobic organisms (Shila et al. 2005) to protect cells against some of the oxidative damage caused by ROS.

Catalase (CAT) is a common enzyme found in nearly all organisms that are exposed to oxygen, and its function is to catalyze the decomposition of $\mathrm{H}_{2} \mathrm{O}_{2}$ to $\mathrm{O}_{2}$ and $\mathrm{H}_{2} \mathrm{O}$. CAT can also oxidize different toxins such as formaldehyde, formic acid, phenol, alcohols, etc. Lipid peroxidation (LPO) is a well-established mechanism for estimating cellular injury in both plants and animals, and it is used as an indicator of oxidative stress in cells and tissues. Reduced glutathione (GSH) is an antioxidant that helps to protect cells from ROS such as free radicals and peroxides. It is found exclusively in its reduced form.

Zebrafish, Danio rerio, was selected for the present study because they are model organisms for toxicological research, and are also recommended by the International Organization for Standardization and the Organization for Economic Co-operation and Development (OECD 1992). The present study focused on the toxic effect of dimethoate on the activity of CAT, GSH, and LPO in the gills and livers of Danio rerio. The study focused on the gills because these are the first organs that come into contact with xenobiotics in waters. The liver is associated with detoxification and biotransformation processes, and because of its function, position, and blood supply, it is also one of the organs that is most affected by contaminants in waters (Rekha et al. 2008).

\section{Materials and methods}

Zebrafish were collected, acclimatized for 15 days, stocked, and reared under laboratory conditions. The aquariums were aerated continuously through stone diffusers connected to a mechanical air compressor. The water temperature was $25^{\circ} \mathrm{C}( \pm 2)$, and $\mathrm{pH}$ was maintained between 6.6 and 8.5. The fish were fed twice daily alternately with raw, chopped goat liver and brine shrimp pellets prepared in our laboratory. The diet was supplemented with Drosophila flies once daily.

For the present study, mature adult zebrafish approximately $3.5 \mathrm{~cm}$ in length and $1.4 \mathrm{~g}$ in weight were procured from stock aquariums and exposed to four different concentrations of 20\% $\left(12.00 \mu \mathrm{g} \mathrm{L}^{-1}\right)$, $40 \%\left(24.00 \mu \mathrm{g} \mathrm{L}^{-1}\right), 60 \%\left(36.00 \mu \mathrm{g} \mathrm{L}^{-1}\right)$, and $80 \%$ $\left(48.00 \mu \mathrm{g} \mathrm{L}^{-1}\right)$ of the $96-\mathrm{h} \mathrm{LC}_{50}$ value of dimethoate calculated from our previous toxicity test (Ansari and Ansari 2011). Low concentrations were selected since fish can survive the stress of the toxicant. Fifty fish were exposed to each pesticide concentration. The water in these aquariums was replaced daily with fresh pesticide treatments. The experiment was accompanied by a control. After exposure periods of 7,14 , and 21 days, the required number of exposed fish was removed from the experimental and control groups. Their gills and livers were excised and processed.

LPO levels were estimated with thiobarbituric acid reacting substances (TBARS) and color reaction for malondialdehyde (MDA) according to procedures in Placer et al. (1966). Tissues were homogenized in chilled $0.15 \mathrm{M} \mathrm{KCl}$ using a Teflon pestle to obtain $10 \% \mathrm{w} / \mathrm{v}$ homogenate. One $\mathrm{ml}$ of homogenate was incubated at $37^{\circ} \mathrm{C}( \pm 0.5)$ for two hours. To each sample, $1 \mathrm{ml}$ of $10 \% \mathrm{w} / \mathrm{v}$ trichloro acetic acid (TCA) (s.d. Fine-Chem Ltd., Mumbai) was added. After thorough mixing, the reaction mixture was centrifuged at $2000 \mathrm{rpm}$ for 10 minutes. One $\mathrm{ml}$ of supernatant was then taken with an equal volume of $0.67 \% \mathrm{w} / \mathrm{v}$ TBA (HiMedia Lab., Pvt. Ltd., Mumbai) and kept in a boiling water bath for 10 minutes, cooled, and diluted with $1 \mathrm{ml}$ of distilled water. The absorbance of the 
color pink obtained was measured at $535 \mathrm{~nm}$ against a blank. The concentration of MDA was read from a standard calibration curve plotted using 1,1,3,3' tetra-methoxypropane (Sigma-Aldrich Co., St. Louis, USA) and the results were expressed as $\mu \mathrm{mol}$ of MDA formed $30 \mathrm{~min}^{-1} \mathrm{mg}$ protein ${ }^{-1}$.

The activity of CAT (EC 1.11.1.6) was estimated according to procedures by Sinha (1972). This method is based on the fact that in acetic acid dichromate is reduced to chromic acetate when heated in the presence of $\mathrm{H}_{2} \mathrm{O}_{2}$ with the formation of perchromic acid as an unstable intermediate. The chromic acetate is measured colorimetrically at 620 $\mathrm{nm}$. The catalase preparation is allowed to split $\mathrm{H}_{2} \mathrm{O}_{2}$ at different time intervals by the addition of a dichromic acetic acid mixture and the remaining $\mathrm{H}_{2} \mathrm{O}_{2}$ is determined colorimetrically. The results were expressed as $\mu \mathrm{mol} \mathrm{H}_{2} \mathrm{O}_{2}$ utilized min $^{-1} \mathrm{mg}_{\text {protein }}{ }^{-1}$.

The GSH level was estimated using the method by Paglia et al. (1975), with which it is determined by its reaction with 5,5'-dithio-bis-2-nitrobenzoic acid (DTNB) to yield a yellow chromophore that was measured spectrophotometrically at $412 \mathrm{~nm}$, The results were expressed as GSH mg per mg protein ${ }^{-1}$. The protein contents of tissues were assayed using the
Lowry et al. (1951) method with bovine serum albumin as the standard.

Two way analysis of variance (ANOVA) was applied to test the significance of the data. All the data are expressed as means $(n=6) \pm$ standard deviation (SD) and differences were considered significant at $\mathrm{P}$ $<0.05$.

\section{Results}

Abnormal behaviors such as restlessness and sudden, quick, jerky movements were observed in the group of fish that were treated at low concentrations of pesticides, whereas the fish exposed to high concentrations exhibited increased opercular movements accompanied by surface to bottom movements and a loss of equilibrium.

Tables 1 and 2 present the changes in CAT activity in the gills and livers of $D$. rerio in response to concentrations of 12.00, 24.00, 36.00, and $48.00 \mu \mathrm{g} \mathrm{L}^{-1}$ (20, 40, 60, and $80 \%$ of $\left.96-\mathrm{L} \mathrm{LC}_{50}\right)$ of dimethoate for 7,14 , and 21 days of exposure. CAT activity was significantly decreased in both tissue types after the exposure periods. After 7 days of exposure to $20 \% 96-\mathrm{h}$

Table 1

Effect of dimethoate on catalase activity (CAT) in the gills of zebrafish (D. rerio). CAT activity was calculated as $\mu$ mol $\mathrm{H}_{2} \mathrm{O}_{2}$ consumed $\mathrm{min}^{-1} \mathrm{mg}$ protein ${ }^{-1}$. Values are means $\pm \mathrm{SD}$ of six individual observations and are significant at $\mathrm{P}<0.05$ (two-way ANOVA)

\begin{tabular}{|c|c|c|c|c|c|c|c|c|c|}
\hline \multirow[b]{2}{*}{$\begin{array}{l}\text { Concentrations } \\
\left(\mu \mathrm{g} \mathrm{L}^{-1}\right)^{*}\end{array}$} & \multicolumn{3}{|c|}{ Exposure period (days) } & \multicolumn{6}{|c|}{ Summary of ANOVA computations } \\
\hline & 7 & 14 & 21 & $\begin{array}{l}\text { Source } \\
\text { of variations }\end{array}$ & df & $\begin{array}{l}\text { Sum } \\
\text { of squares }\end{array}$ & $\begin{array}{l}\text { Mean } \\
\text { of squares }\end{array}$ & $\mathrm{F}$ & $\mathrm{P}$ \\
\hline Control & $\begin{array}{l}169.41 \pm 0.23 \\
(100)\end{array}$ & $\begin{array}{l}169.61 \pm 0.55 \\
(100)\end{array}$ & $\begin{array}{l}169.83 \pm 0.11 \\
(100)\end{array}$ & $\begin{array}{l}\text { Variations due to } \\
\text { concentrations }\end{array}$ & 2 & 4336.50 & 2168.25 & 12703.02 & 0.05 \\
\hline 12.00 & $\begin{array}{l}160.95 \pm 0.64 \\
(95)\end{array}$ & $\begin{array}{l}156.04 \pm 0.56 \\
(92)\end{array}$ & $\begin{array}{l}147.75 \pm 0.15 \\
(87)\end{array}$ & $\begin{array}{l}\text { Variations due to } \\
\text { operations }\end{array}$ & 4 & 33296.17 & 8324.04 & 48767.65 & 0.05 \\
\hline 24.00 & $\begin{array}{l}157.56 \pm 0.34 \\
(93)\end{array}$ & $\begin{array}{l}150.95 \pm 0.64 \\
(89)\end{array}$ & $\begin{array}{l}142.67 \pm 0.56 \\
(84)\end{array}$ & Interaction & 8 & 2540.41 & 317.55 & 1860.42 & 0.05 \\
\hline 36.00 & $\begin{array}{l}140.61 \pm 0.55 \\
(83)\end{array}$ & $\begin{array}{l}132.28 \pm 0.13 \\
(78)\end{array}$ & $\begin{array}{l}115.49 \pm 0.29 \\
(68)\end{array}$ & Residual & 75 & 12.80 & 0.17 & & \\
\hline 48.00 & $\begin{array}{l}135.54 \pm 0.22 \\
(80)\end{array}$ & $\begin{array}{l}106.84 \pm 0.12 \\
(63)\end{array}$ & $\begin{array}{l}103.59 \pm 0.34 \\
(60)\end{array}$ & Total & 89 & 40185.88 & & & \\
\hline
\end{tabular}

*The exposure concentrations used were $20,40,60$, and $80 \%$ of the $96-\mathrm{h} \mathrm{LC}_{50}$ value. Values in parentheses indicate percentage changes to the nearest whole values with the control value as $100 \%$. 
Table 2

Effect of dimethoate on catalase activity (CAT) in the liver of zebrafish (D. rerio). CAT activity calculated as $\mu_{\text {mol }} \mathrm{H}_{2} \mathrm{O}_{2}$ consumed $\min ^{-1} \mathrm{mg}$ protein ${ }^{-1}$. Values are means $\pm \mathrm{SD}$ of six individual observations and are significant at $\mathrm{P}<0.05$ (two-way ANOVA)

\begin{tabular}{|c|c|c|c|c|c|c|c|c|c|}
\hline \multirow[b]{2}{*}{$\begin{array}{l}\text { Concentrations } \\
\left(\mu \mathrm{g} \mathrm{L}^{-1}\right)^{*}\end{array}$} & \multicolumn{3}{|c|}{ Exposure period (days) } & \multicolumn{6}{|c|}{ Summary of ANOVA computations } \\
\hline & 7 & 14 & 21 & $\begin{array}{l}\text { Source } \\
\text { of variations }\end{array}$ & df & $\begin{array}{l}\text { Sum } \\
\text { of squares }\end{array}$ & $\begin{array}{l}\text { Mean } \\
\text { of squares }\end{array}$ & $\mathrm{F}$ & $\mathrm{P}$ \\
\hline Control & $\begin{array}{l}181.41 \pm 0.22 \\
(100)\end{array}$ & $\begin{array}{l}181.83 \pm 0.11 \\
(100)\end{array}$ & $\begin{array}{l}180.61 \pm 0.55 \\
(100)\end{array}$ & $\begin{array}{l}\text { Variations due to } \\
\text { concentrations }\end{array}$ & 2 & 7523.89 & 3761.94 & 22617.98 & 0.05 \\
\hline 12.00 & $\begin{array}{l}168.70 \pm 0.17 \\
(93)\end{array}$ & $\begin{array}{l}160.01 \pm 0.75 \\
(88)\end{array}$ & $\begin{array}{l}149.91 \pm 0.64 \\
\text { (83) }\end{array}$ & $\begin{array}{l}\text { Variations due to } \\
\text { operations }\end{array}$ & 4 & 47438.93 & 11859.73 & 71304.43 & 0.05 \\
\hline 24.00 & $\begin{array}{l}161.46 \pm 0.28 \\
(89)\end{array}$ & $\begin{array}{l}154.56 \pm 0.34 \\
(85)\end{array}$ & $\begin{array}{l}144.49 \pm 0.20 \\
(80)\end{array}$ & Interaction & 8 & 3471.53 & 433.94 & 2608.99 & 0.05 \\
\hline 36.00 & $\begin{array}{l}146.94 \pm 0.64 \\
(81)\end{array}$ & $\begin{array}{l}132.75 \pm 0.15 \\
(73)\end{array}$ & $\begin{array}{l}115.59 \pm 0.22 \\
(64)\end{array}$ & Residual & 75 & 12.47 & 0.17 & & \\
\hline 48.00 & $\begin{array}{l}139.68 \pm 0.25 \\
(77)\end{array}$ & $\begin{array}{l}109.08 \pm 0.56 \\
(60)\end{array}$ & $\begin{array}{l}95.70 \pm 0.17 \\
(53)\end{array}$ & Total & 89 & 58446.82 & & & \\
\hline
\end{tabular}

*The exposure concentrations used were $20,40,60$, and $80 \%$ of the $96-\mathrm{h} \mathrm{LC}_{50}$ value. Other details as in Table 1.

$\mathrm{LC}_{50}$ of dimethoate, CAT activity declined to $95 \%$ $(160.95 \pm 0.64)$ and $93 \%(168.70 \pm 0.17)$ of controls (100\%) in gills and livers, respectively. However, after 21 days of exposure to $80 \% 96-\mathrm{h} \mathrm{LC}_{50}$ of this pesticide, the activity was found to be $60 \%$ (103.59 \pm $0.34)$ and $53 \%(95.70 \pm 0.17)$ in the gills and livers, which was a reduction of $40 \%$ and $47 \%$, respectively.

The GSH level was found to be 97\% (2.27 \pm $0.14)$ and $96 \%(3.46 \pm 0.28)$ of controls $(100 \%)$ in the gills and livers, respectively, after exposure to
20\% 96-h $\mathrm{LC}_{50}$ for 7 days. At $60 \%$ 96-h $\mathrm{LC}_{50}$ for 21 days, the GSH level remained only $65 \%(1.43 \pm 0.19)$ in the gills and $57 \%(1.79 \pm 0.73)$ in the livers. Maximum inhibition was observed after 21 days. The $80 \%$ 96-h LC $50\left(48.00 \mu \mathrm{g} \mathrm{L}^{-1}\right)$ dose of dimethoate caused levels of GSH to decrease by $59 \%(1.32 \pm 0.14)$ in the gills and $51 \%(1.59 \pm 0.22)$ in the livers in comparison to the control (100\%) values after 21 days of exposure (Tables 3 and 4).

Table 3

Effect of dimethoate on reduced glutathione (GSH) in the gills of zebrafish (D. rerio). GSH values calculated as mg GSH mg ${ }^{-1}$ protein. Values are means \pm SD of six individual observations and are significant at $\mathrm{P}<0.05$ (two-way ANOVA)

\begin{tabular}{|c|c|c|c|c|c|c|c|c|c|}
\hline \multirow[b]{2}{*}{$\begin{array}{l}\text { Concentrations } \\
\left(\mu \mathrm{g} \mathrm{L}^{-1}\right)^{*}\end{array}$} & \multicolumn{3}{|c|}{ Exposure period (days) } & \multicolumn{6}{|c|}{ Summary of ANOVA computations } \\
\hline & 7 & 14 & 21 & $\begin{array}{l}\text { Source } \\
\text { of variations }\end{array}$ & df & $\begin{array}{l}\text { Sum } \\
\text { of squares }\end{array}$ & $\begin{array}{l}\text { Mean } \\
\text { of squares }\end{array}$ & $\mathrm{F}$ & $\mathrm{P}$ \\
\hline Control & $\begin{array}{l}2.34 \pm 0.14 \\
(100)\end{array}$ & $\begin{array}{l}2.41 \pm 0.21 \\
(100)\end{array}$ & $\begin{array}{l}2.21 \pm 0.10 \\
(100)\end{array}$ & $\begin{array}{l}\text { Variations due to } \\
\text { concentrations }\end{array}$ & 2 & 3.19 & 1.60 & 7.38 & 0.05 \\
\hline 12.00 & $\begin{array}{l}2.27 \pm 0.14 \\
(97)\end{array}$ & $\begin{array}{l}2.23 \pm 0.67 \\
(93)\end{array}$ & $\begin{array}{l}1.97 \pm 0.64 \\
(89)\end{array}$ & $\begin{array}{l}\text { Variations due to } \\
\text { operations }\end{array}$ & 4 & 4.18 & 1.04 & 4.83 & 0.05 \\
\hline 24.00 & $\begin{array}{l}2.16 \pm 0.53 \\
(92)\end{array}$ & $\begin{array}{l}2.12 \pm 0.05 \\
(88)\end{array}$ & $\begin{array}{l}1.83 \pm 0.55 \\
(83)\end{array}$ & Interaction & 8 & 0.82 & 0.10 & 0.47 & NS \\
\hline 36.00 & $\begin{array}{l}2.08 \pm 0.56 \\
(89)\end{array}$ & $\begin{array}{l}2.00 \pm 0.56 \\
(83)\end{array}$ & $\begin{array}{l}1.43 \pm 0.19 \\
(65)\end{array}$ & Residual & 75 & 16.21 & 0.22 & & \\
\hline 48.00 & $\begin{array}{l}2.04 \pm 0.56 \\
(87)\end{array}$ & $\begin{array}{l}1.78 \pm 0.53 \\
(74)\end{array}$ & $\begin{array}{l}1.32 \pm 0.14 \\
(59)\end{array}$ & Total & 89 & 24.39 & & & \\
\hline
\end{tabular}

*The exposure concentrations used were $20,40,60$, and $80 \%$ of the $96-\mathrm{h} \mathrm{LC}_{50}$ value. Other details as in Table 1 . NS - not significant. 
Table 4

Effect of dimethoate on GSH (GSH mg mg protein ${ }^{-1}$ ) in the livers of zebrafish (D. rerio). GSH values calculated as mg GSH mg ${ }^{-1}$ protein. Values are means \pm SD of six individual observations and are significant at $\mathrm{P}<0.05$ (two-way ANOVA)

\begin{tabular}{|c|c|c|c|c|c|c|c|c|c|}
\hline \multirow[b]{2}{*}{$\begin{array}{l}\text { Concentrations } \\
\left(\mu \mathrm{g} \mathrm{L}^{-1}\right)^{*}\end{array}$} & \multicolumn{3}{|c|}{ Exposure period (days) } & \multicolumn{6}{|c|}{ Summary of ANOVA computations } \\
\hline & 7 & 14 & 21 & $\begin{array}{l}\text { Source } \\
\text { of variations }\end{array}$ & df & $\begin{array}{l}\text { Sum } \\
\text { of squares }\end{array}$ & $\begin{array}{l}\text { Mean } \\
\text { of squares }\end{array}$ & $\mathrm{F}$ & $\mathrm{P}$ \\
\hline Control & $\begin{array}{l}3.59 \pm 0.34 \\
(100)\end{array}$ & $\begin{array}{l}3.68 \pm 0.25 \\
(100)\end{array}$ & $\begin{array}{l}3.12 \pm 0.07 \\
(100)\end{array}$ & $\begin{array}{l}\text { Variations due to } \\
\text { concentrations }\end{array}$ & 2 & 14.39 & 7.19 & 39.94 & 0.05 \\
\hline 12.00 & $\begin{array}{l}3.46 \pm 0.28 \\
(96)\end{array}$ & $\begin{array}{l}3.31 \pm 0.64 \\
(90)\end{array}$ & $\begin{array}{l}2.63 \pm 0.56 \\
(84)\end{array}$ & $\begin{array}{l}\text { Variations due to } \\
\text { operations }\end{array}$ & 4 & 17.10 & 4.28 & 23.74 & 0.05 \\
\hline 24.00 & $\begin{array}{l}3.34 \pm 0.64 \\
(93)\end{array}$ & $\begin{array}{l}3.03 \pm 0.24 \\
(82)\end{array}$ & $\begin{array}{l}2.33 \pm 0.14 \\
(75)\end{array}$ & Interaction & 8 & 1.27 & 0.16 & 0.88 & 0.05 \\
\hline 36.00 & $\begin{array}{l}2.91 \pm 0.38 \\
(81)\end{array}$ & $\begin{array}{l}2.91 \pm 0.67 \\
(79)\end{array}$ & $\begin{array}{l}1.79 \pm 0.73 \\
(57)\end{array}$ & Residual & 75 & 13.51 & 0.18 & & \\
\hline 48.00 & $\begin{array}{l}2.72 \pm 0.18 \\
(76)\end{array}$ & $\begin{array}{l}2.36 \pm 0.13 \\
(64)\end{array}$ & $\begin{array}{l}1.59 \pm 0.22 \\
(51)\end{array}$ & Total & 89 & 46.27 & & & \\
\hline
\end{tabular}

*The exposure concentrations used were $20,40,60$, and $80 \%$ of the $96-\mathrm{h} \mathrm{LC}_{50}$ value. Other details as in Table 1.

The MDA concentration in the gills and livers of fish exposed to dimethoate showed no change at the lowest concentration after 7 days, but after 14 days at 40\% 96-h $\mathrm{LC}_{50}$, change was observed, and MDA content increased to $119 \%(8.83 \pm 0.11)$ and $123 \%$ (16.16 \pm 0.59$)$ in the gills and livers, respectively, in comparison to the control. At $60 \% 96-\mathrm{h} \mathrm{LC}_{50}$ for 21 days of exposure, MDA levels further increased to
$145 \%(11.42 \pm 0.19)$ in the gills and 148\% (19.69 \pm $0.17)$ in the livers. The MDA content increased to $154 \%(12.12 \pm 0.65)$ in the gills and 159\% (21.19 \pm 0.11 ) in the livers after exposure to $80 \% 96-\mathrm{h} \mathrm{LC}_{50}$ (48.00 $\mu \mathrm{g} \mathrm{L}^{-1}$ ) of dimethoate after 21 days (Tables 5 and 6). The result indicate that the changes in enzyme activity during the present study were dependent on time and concentration.

Table 5

Effect of dimethoate on lipid peroxidation (LPO) in the gills of zebrafish (D. rerio). LPO values calculated as $\mu$ mol of MDA formed $30 \mathrm{~min}^{-1} \mathrm{mg}^{-1}$ protein. Values are means $\pm \mathrm{SD}$ of six individual observations and are significant at $\mathrm{P}<0.05$ (two-way ANOVA)

\begin{tabular}{|c|c|c|c|c|c|c|c|c|c|}
\hline \multirow[b]{2}{*}{$\begin{array}{l}\text { Concentrations } \\
\left(\mu \mathrm{g} \mathrm{L}^{-1}\right)^{*}\end{array}$} & \multicolumn{3}{|c|}{ Exposure period (days) } & \multicolumn{6}{|c|}{ Summary of ANOVA computations } \\
\hline & 7 & 14 & 21 & $\begin{array}{l}\text { Source } \\
\text { of variations }\end{array}$ & $\mathrm{df}$ & $\begin{array}{l}\text { Sum } \\
\text { of squares }\end{array}$ & $\begin{array}{l}\text { Mean } \\
\text { of squares }\end{array}$ & $\mathrm{F}$ & $\mathrm{P}$ \\
\hline Control & $\begin{array}{l}7.16 \pm 0.53 \\
(100)\end{array}$ & $\begin{array}{l}7.41 \pm 0.19 \\
(100)\end{array}$ & $\begin{array}{l}7.87 \pm 0.42 \\
(100)\end{array}$ & $\begin{array}{l}\text { Variations due to } \\
\text { concentrations }\end{array}$ & 2 & 54.15 & 27.08 & 147.69 & 0.05 \\
\hline 12.00 & $\begin{array}{l}7.31 \pm 0.64 \\
(102)\end{array}$ & $\begin{array}{l}7.79 \pm 0.73 \\
(105)\end{array}$ & $\begin{array}{l}8.75 \pm 0.15 \\
(111)\end{array}$ & $\begin{array}{l}\text { Variations due to } \\
\text { operations }\end{array}$ & 4 & 119.84 & 29.96 & 163.43 & 0.05 \\
\hline 24.00 & $\begin{array}{l}8.08 \pm 0.24 \\
(113)\end{array}$ & $\begin{array}{l}8.83 \pm 0.11 \\
(119)\end{array}$ & $\begin{array}{l}9.61 \pm 0.55 \\
(122)\end{array}$ & Interaction & 8 & 11.48 & 1.43 & 7.83 & 0.05 \\
\hline 36.00 & $\begin{array}{l}8.67 \pm 0.26 \\
(121)\end{array}$ & $\begin{array}{l}9.79 \pm 0.55 \\
(132)\end{array}$ & $\begin{array}{l}11.42 \pm 0.19 \\
(145)\end{array}$ & Residual & 75 & 13.75 & 0.18 & & \\
\hline 48.00 & $\begin{array}{l}9.09 \pm 0.24 \\
(127)\end{array}$ & $\begin{array}{l}10.37 \pm 0.16 \\
(140)\end{array}$ & $\begin{array}{l}12.12 \pm 0.65 \\
(154)\end{array}$ & Total & 89 & 119.22 & & & \\
\hline
\end{tabular}

*The exposure concentrations used were $20,40,60$, and $80 \%$ of the $96-\mathrm{LC}_{50}$ value. Other details as in Table 1. 
Table 6

Effect of dimethoate on LPO ( $\mu \mathrm{mol}$ of MDA formed $30 \mathrm{~min}^{-1} \mathrm{mg}$ protein ${ }^{-1}$ ) in the livers of zebrafish $(D$. rerio). LPO values calculated as $\mu \mathrm{mol}$ of MDA formed $30 \mathrm{~min}^{-1} \mathrm{mg}^{-1}$ protein. Values are means $\pm \mathrm{SD}$ of six individual observations and are significant at $\mathrm{P}<0.05$ (two-way ANOVA)

\begin{tabular}{|c|c|c|c|c|c|c|c|c|c|}
\hline \multirow[b]{2}{*}{$\begin{array}{l}\text { Concentrations } \\
\left(\mu \mathrm{g} \mathrm{L}^{-1}\right)^{*}\end{array}$} & \multicolumn{3}{|c|}{ Exposure period (days) } & \multicolumn{6}{|c|}{ Summary of ANOVA computations } \\
\hline & 7 & 14 & 21 & $\begin{array}{l}\text { Source } \\
\text { of variations }\end{array}$ & $\mathrm{df}$ & $\begin{array}{l}\text { Sum } \\
\text { of squares }\end{array}$ & $\begin{array}{l}\text { Mean } \\
\text { of squares }\end{array}$ & $\mathrm{F}$ & $\mathrm{P}$ \\
\hline Control & $\begin{array}{l}13.99 \pm 0.39 \\
(100)\end{array}$ & $\begin{array}{l}13.15 \pm 0.56 \\
(100)\end{array}$ & $\begin{array}{l}13.32 \pm 0.64 \\
(100)\end{array}$ & $\begin{array}{l}\text { Variations due to } \\
\text { concentrations }\end{array}$ & 2 & 35.95 & 17.98 & 103.59 & 0.05 \\
\hline 12.00 & $\begin{array}{l}14.55 \pm 0.22 \\
(104)\end{array}$ & $\begin{array}{l}14.71 \pm 0.17 \\
(112)\end{array}$ & $\begin{array}{l}15.98 \pm 0.65 \\
(120)\end{array}$ & $\begin{array}{l}\text { Variations due to } \\
\text { operations }\end{array}$ & 4 & 455.79 & 113.95 & 656.65 & 0.05 \\
\hline 24.00 & $\begin{array}{l}16.09 \pm 0.56 \\
(115)\end{array}$ & $\begin{array}{l}16.16 \pm 0.59 \\
(123)\end{array}$ & $\begin{array}{l}17.70 \pm 0.17 \\
(133)\end{array}$ & Interaction & 8 & 17.32 & 2.17 & 12.48 & 0.05 \\
\hline 36.00 & $\begin{array}{l}17.77 \pm 0.53 \\
(127)\end{array}$ & $\begin{array}{l}17.88 \pm 0.42 \\
(136)\end{array}$ & $\begin{array}{l}19.69 \pm 0.17 \\
(148)\end{array}$ & Residual & 75 & 13.01 & 0.17 & & \\
\hline 48.00 & $\begin{array}{l}18.74 \pm 0.14 \\
(134)\end{array}$ & $\begin{array}{l}19.33 \pm 0.14 \\
(147)\end{array}$ & $\begin{array}{l}21.19 \pm 0.11 \\
(159)\end{array}$ & Total & 89 & 522.08 & & & \\
\hline
\end{tabular}

*The exposure concentrations used were $20,40,60$, and $80 \%$ of the $96-\mathrm{h} \mathrm{LC}_{50}$ value. Other details as in Table 1.

\section{Discussion}

Lipid peroxidation in vivo has been identified as one of the basic deteriorative reactions in cellular mechanisms of pesticide-induced oxidative stress in freshwater fishes. The dose-dependent enhancement in the level of lipid peroxidation observed in this study concurs with the results of many other researchers (Pandey et al. 2001, Agrahari et al. 2006, Modesto and Martinez 2010). The elevated levels of LPO in the gills and livers of D. rerio in response to 21 days of exposure to dimethoate that were observed during the present study suggest that production of ROS is increased, which could be associated with the metabolism of the dimethoate pesticide leading to the peroxidation of membrane lipids in both types of tissues. The liver is noted as a site of multiple oxidative reactions and maximum free radical generation (Atli et al. 2006). Researchers have reported previously LPO induction by pesticides such as alachlor (Peebua et al. 2007), malathion (Chandra 2008), and butachlor (Farombi et al. 2008) in fishes, and deltamethrin in fresh water mussels (Köprücü et al. 2008). LPO has also been used to measure xenobiotic-induced oxidative stresses, which were originally defined as the disequilibrium between pro-oxidants and antioxidants in biological systems. Once this imbalance appears, cellular macromolecules can be damaged by predominant free radicals. The impairment of enzymatic antioxidant system can facilitate the accumulation of free radicals that might be responsible for increased lipid peroxidation with pesticide exposure. Thus, they are used as markers of oxidative stress. Increases in MDA levels indicate the enhancement of hepatic LPO. Pant and Gill (1987) also report an increase in lipid peroxidation in the livers and muscles of Pethia (=Barbus) chonchonius (Hamilton) that were exposed to aldicarb, which concurs with the present results.

CAT is the primary enzyme responsible for eliminating the ROS formed during bioactivation of xenobiotics in hepatic tissues (Sk and Bhattacharya 2006), and the induction of CAT system provides the first line of defense against ROS. CAT activity, however, gradually decreased after 7, 14, and 21 days of exposure to dimethoate, and the values obtained were significantly $(\mathrm{P}<0.05)$ lower than those of the control. Decreased CAT activity could stem from decreases in reaction rates resulting from the excess production of $\mathrm{H}_{2} \mathrm{O}_{2}$. This could have been because of the flux of superoxide radicals, which has been shown to inhibit CAT activity (Ahmad et al. 2000). That sub-lethal 
concentrations of dimethoate induce oxidative stress in $D$. rerio could be an adaptive response to protect fish from dimethoate-induced free radical toxicity. The dose-dependent decrease in the activity of catalase observed during the present study has also been observed by other investigators (Kono and Fridovich 1982, Sayeed et al. 2003, Crestani et al. 2007, Kubrak et al. 2010, Singh et al. 2012). Similarly, Jee and Kang (2005) also observed a decrease in catalase activity in the gills, livers, and kidneys of Paralicthys olivaceus (Temminck \& Schlegel) after phenanthrene exposure. Recently, Tripathi and Singh (2013) observed a decrease in CAT activity in the brains, gills, livers, and skeletal muscles of Channa punctatus (Bloch). The increase or decrease of enzyme activity is related to the intensity of cellular damage.

The term "antioxidant" is used to define cells' own protective mechanisms. The reduced glutathione (GSH) antioxidant system is the principal protective mechanism of cells, and is a crucial factor in the development of the immune response by immune cells. Glutathione (L-gamma-glutamyl-L-cysteinylgyl-cine) can spontaneously, or with the help of peroxidase, easily deliver the $\mathrm{H}^{+}$necessary for the reduction of radicals. In both cases, the active element is the $\mathrm{SH}$ (thiol) group of cysteine which, when performing its antioxidant activity, is oxidized to cystine or cysteine disulfide. The ratio of cysteine/cystine defines the redox state, which is the major determinant of optimal cell function. Cysteine is the limiting factor of GSH synthesis in cells, and reduced glutathione has sulfide functional groups that can capture unpaired electrons, and, thus, is capable of removing harmful free radicals (Pickering and Wiesner 2005).

During the present study, it was noted that 21 days of continuous exposure resulted in significant decreases in GSH levels in zebrafish gills and livers. The decreased levels of CAT and GSH levels in the tissues (gills and livers) could account for the marked lipid peroxidation observed. The significant decrease in GSH levels was also observed by Achudume et al. (2010) and Jin et al. (2011). The fish gills are the organs that are most exposed to contaminated waters, and these contaminants can penetrate through their thin epithelial cells (Gül et al. 2004). Furthermore, the apparent decrease in the glutathione detoxification system in the gills, the first point of contact with environmental xenobiotics, indicates that this system is a sensitive biochemical indicator of environmental pollution in Clarias gariepinus (Burchell) (Kono and Fridovich 1982). GSH depletion might enhance the risk of oxidative stress (Regoli and Principato 1995). A considerable decline in GSH content in tissues under the present experimental model could be because of its utilization to challenge the prevailing oxidative stress under the influence of ROS generated from dimethoate-induced oxidative stress. The relevant reduction in GSH levels observed in the present study in tissues (gills and livers) of pesticide-exposed zebrafish, suggest oxidative stress conditions resulting from the over accumulation of ROS.

\section{Conclusions}

The results of the present investigation led to the conclusion that dimethoate intoxication disturbs normal cell functioning and resultant alterations in the fundamental biochemical mechanisms in fish. This results in the mortality of fish at sub-lethal exposures to the pesticide. Additionally, the pesticide can be deposited in fish tissues accidentally or through contaminated water which could lead to changes in overall fish health. This opens new avenues for investigations of adaptive mechanisms in animals, particularly in fish, to environmental hazards. Moreover, these findings document the effects of regular dimethoate exposure to zebrafish and the adverse effects of pesticide in aquatic ecosystems, while also providing a foundation for future research on this topic.

Acknowledgments. The authors are thankful to Prof. V.B. Upadhyay, Head of the Department of Zoology, D.D.U. Gorakhpur University, Gorakhpur for providing laboratory facilities during this research project.

Author contribution. S.A. performed the biochemical experiments and wrote the manuscript, B.A.A. designed the experiments and computed the results. 


\section{References}

Achudume A.C., Nwoha P.U., Ibe J.N. 2010 - Effects of dietary exposure to insecticide "Raid" on the survival, growth and inhibition of metabolic processes in Wistar rats - J. Environ. Chem. Ecotoxicol. 2: 120-125.

Agrahari S., Gopal K., Pandey, K.C. 2006 - Biomarkers of monocrotophos in a fresh water fish, Channa punctatus (Bloch) - J. Environ. Biol. 27: 453-457.

Ahmad I., Hamid T., Fatima M., Chand H.S., Jain S.K., Athar M., Raisuddin S. 2000 - Induction of hepatic antioxidants in freshwater catfish (Channa punctatus Bloch) is a biomarker of paper mill effluent exposure - Biochim. Biophys. Acta-Biomembr. 1523: 37-48.

Ansari S., Ansari, B.A. 2011 - Embryo and fingerling toxicity of Dimethoate and effect on fecundity, viability and survival of zebrafish, Danio rerio (Cyprinidae) - World J. Fish Marine Sci. 3: 167-173.

Ansari S., Ansari B.A. 2012 - Alphamethrin toxicity: Effect on the reproductive ability and the activities of phosphatases in the tissues of zebrafish, Danio rerio - Int. J. Life Sci. Pharma. Res. 2: 89-100.

Atli G., Alptekin O., Tukel S., Canlin M. 2006 - Response of catalase activity to $\mathrm{Ag}^{+}, \mathrm{Cd}^{+}, \mathrm{Cr}^{6+}, \mathrm{Cu}^{2+}$ and $\mathrm{Zn}^{2+}$ in five tissues of fresh water fish, Oreochromis niloticus - Comp. Biochem. Physiol. Part C 143: 218-224.

Chandra S. 2008 - Toxic effect of malathion to acetylcolinesterase activity of liver, brain and gills of freshwater catfish, Heteropneustis fossilis - Environ. Conserv. 9: 45-52.

Crestani M., Menzes C., Glusczak L., Miron D.S., Spanevello R., Silveira A., Goncalves F.F., Zanella R., Loro V.L. 2007 - Effect of clomazone herbicide on biochemical and histological aspects of silver catfish (Ramdia quelen) and recovery pattern - Chemosphere 67: 2305-2311.

Farombi E.O., Ajimoko Y.R., Adelowo O.A. 2008 - Effect of Butachlor on antioxidant enzyme status and lipid peroxidation in freshwater African catfish, Clarias gariepinus - Int. J. Environ. Res. Public. Health 5: 423-427.

Gram T. 1997 - Chemical reactive intermediates and pulmonary xenobiotic toxicity - Pharmacological Rev. 49: 297-342.

Gül S., Belge-Kurutas E., Yildiz E., Sahan A., Doran F. 2004 Pollution correlated modifications of liver antioxidant systems and histopathology of fish (Cyprinidae) living in Seyhan Dan Lake, Turkey - Environ. Int. 30: 605-609.

Gultekin F., Ozsturk M., Akdogan M. 2000 - The effect of organophosphate insecticide chlorpyrifosethyl on lipid-peroxidation and antioxidant enzymes (in vitro) Arch. Toxicol. 74: 533-538.
Hoegberg E.I., Cassaday, J.T. 1951 - The reaction of O, O-dialkyl thiophosphoric acid salts some alpha-haloacyl derivatives - J. Am. Chem. Soc. 73: 557-559.

Jee J.H., Kang, J.C. 2005 - Biochemical changes of enzymatic defence system after phenanthrene exposure in olive flounder, Paralichthys olivaceus - Physiol. Res. 54: 585-591.

Jin Y., Zheng S., Pu Y., Shu L., Sun L., Liu W., Fu Z. 2011 Cypermethrin has the potential to induce hepatic oxidative stress, DNA damage and apoptosis in adult zebrafish (Danio rerio) - Chemosphere 82: 398-404.

Kono Y., Fridovich I. 1982 - Superoxide radical inhibits catalase - J. Biol. Chem. 257: 5751-5754.

Köprücü S.S., Yanar E., Seker E. 2008 - Effects of Deltamethrin on antioxidant status and oxidative stress biomarkers in fresh water mussel Unio elongatulus euchres - Bull. Environ. Contam. Toxicol. 81: 253-257.

Kubrak O.I., Lushchak O.V., Lushchak J.V., Torous I.M., Storey J.M., Storey K.B., Lushchak V.I. 2010 - Chromium effects on free radical processes in goldfish tissues: Comparison of $\mathrm{Cr}$ (iii) and $\mathrm{Cr}$ (vi) exposures on oxidative stress markers, glutathione status and antioxidant enzymes - Comp. Biochem. Physiol. Part C 152: 360-370.

Lowry O.H., Rosenbrough N.J., Farr A.L., Randall R.J. 1951 Protein measurement with Folin phenol reagent - J. Biol. Chem. 193: 265-275.

Maxwell, S.R.J. 1995 - Prospects of the use of antioxidant therapies - Drugs 49: 345-361.

Modesto K.A., Martinez C.B.R. 2010 - Effects of Roundup Transorb on fish: Haematology, antioxidants, defences and acetyl cholinesterase activity - Chemosphere 81 : 781-787.

Niwa T., Doi U., Kato Y., Osawa T. 2001 - Antioxidant properties of phenol antioxidants isolate from corn steep liquor - J. Agric. Food Chem. 49: 177-182.

OECD Organisation for Economic Cooperation and Development, 1992 - OECD Guidelines for Testing of Chemicals: Fish, Early Life Stage Toxicity Test, Section 2 - Guideline 210. Paris, France.

Paglia D.E., Valentine W.N., Dahlgren, J.G. 1975 - Effects of low level lead exposure on pyrimidine 5'-nucleotidase and other erythrocyte enzymes. Possible role of pyrimidine 5'-nucleotidase in the pathogenesis of lead induced anemia - J. Clin. Invest. 56: 1164-1169.

Pandey S., Ahmad I., Parvez S., Bin-Hafeez B., Haque R., Raisuddin S. 2001 - Effect of endosulfan on antioxidants of fresh water fish, Channa punctatus Bloch: 1. Protection against lipid peroxidation in liver by copper preexposure - Arch. Environ. Contam. Toxicol. 41: 345-352.

Pant J.H.T., Gill T.S. 1987 - Effects of aldicarb on the blood and tissues of a freshwater fish - Bull. Environ. Contam. Toxicol. 38: 36-41. 
Peebua L.P., Kosiyachinda P., Pokethitiyook P., Kruatrachue M. 2007 - Evaluation of alachlor herbicide impacts on Nile tilapia (Oreochromis niloticus) using biochemical biomarkers - Bull. Environ. Contam. Toxicol. 78: 138-141.

Pickering K.D., Wiesner M.R. 2005 - Fullerol-sensitized production of reactive oxygen species in aqueous solution Environ. Sci. Technol. 39: 1359-1365.

Placer Z.A., Cushman L., Johnson B.C. 1966 - Estimation of product of lipid peroxidation (Malonyldialdehyde) in biochemical systems - Anal. Biochem. 16: 359-364.

Regoli F., Principato G., 1995 - Glutathione dependent and antioxidant enzymes in mussel, Mytilus galloprovincialis, exposed to metals under field and laboratory conditions: Implications for the use of biochemical biomarkers - Aquat. Toxicol. 31: 143-164.

Rekha R.D., Amali A.A., Her G.M., Yeh Y.H., Gong H.Y., Hu S.Y., Lin G.H., Wu J.L. 2008 - Thioacetamide accelerates steatohepatitis, cirrhosis and HCC by expressing $\mathrm{HCV}$ core protein in transgenic zebrafish, Danio rerio Toxicology 14: 11-22.

Riebeiro B.M., Guedes R.N., Oliveira E.E., Santos J.P. 2003 Insecticides resistance and synergism in Brazilian population of Sitophillus zeamais (Coleoptera Curculionida) J. Stored. Prod. Res. 39: 21-31.
Sayeed I., Parvez S., Pandey S., Bin-Hafeez B., Haque R., Raisuddin, S. 2003 - Oxidative stress biomarkers of exposure to Deltamethrin in freshwater fish, Channa punctatus Bloch - Ecotoxicol. Environ. Saf. 56: 295-301.

Sharma D.K., Ahmad M.K., Ansari S., Ansari B.A. 2012 Effect of Deltamethrin and neem-based formulation Achook on activities of phosphatases in tissues of zebrafish, Danio rerio - Int. J. Curr. Res. 4: 12-16.

Shila S., Kokivalani V., Subathra M., Panneerselvam C. 2005 Brain regional responses in antioxidant system to $\alpha$-lipoic acid in As intoxicated rat - Toxicology 201: 25-36.

Sikka S.C., Rajasekaran M., Hellstorm W.J. 1995 - Role of oxidative stress and antioxidant in male infertility - J. Androl. 16: 464-468.

Singh D., Katiyar S., Verma A. 2012 - Role of copper sulphate on oxidative and metabolic enzymes of fresh water fish, Channa punctatus - J. Environ. Analytic. Toxicol. 2: 121.

Sinha A.K. 1972 - Colorimetric assay of Catalase - Anal. Biochem. 47: 389-394.

Sk H.U., Bhattacharya S. 2006 - Prevention of cadmium induced lipid peroxidation, depletion of some antioxidantive enzymes and glutathione by series of organoselenocyanates - Environ. Toxicol. Pharmacol. 22: 298-308.

Tripathi G., Singh H. 2013 - Impact of Alphamethrin on biochemical parameters of Channa punctatus - J. Eniron. Biol. 34: 227-230. 